\title{
Entrepreneurial Behavior and Intentions among Bumiputera's Students
}

\author{
Norasmah Othman ${ }^{1 *}$, Rafiza Mohd Asiar ${ }^{2}$ \\ Faculty of Education Universiti Kebangsaan Malaysia, 43600 Bangi, Selangor, Malaysia
}

\begin{abstract}
Objective - Unemployment and marketability among graduates are the country's current issues. This became clear when the unemployment percentage among graduates continued to increase yearly. Therefore, entrepreneurship education has been chosen as an alternative solution. However, currently, student involvement in entrepreneurship is still low. As low involvement occurs among students, especially those in private colleges, students may lack entrepreneurial behavior and intentions. Therefore, this study aims to identify the level of the entrepreneurial behavior and intentions among Bumiputra's students studying in Kuala Lumpur's private colleges.

Methodology/Technique - A total of 387 students participated in a quantitative survey. Using a questionnaire as the study's research instrument, the data were analyzed using SPSS version 22.0.

Finding - The findings showed that the entrepreneurial behavior and intentions among students are at a moderate level. Pearson correlation coefficients indicated a significantly positive, although moderate, relationship between entrepreneurial behavior and entrepreneurial intentions. The result suggests that to increase the number of entrepreneurs among students in Malaysia, all stakeholders should be involved in inculcating an entrepreneurial culture.

Novelty -An innovative and practical-based entrepreneurship curriculum should be developed to encourage students to choose entrepreneurship as a career option upon graduation.

Type of Paper: Empirical.
\end{abstract}

Keywords: Entrepreneurial Behavior; Entrepreneurial Intention; College Student; Entrepreneurship Education; Bumiputera

Reference to this paper should be made as follows: Othman, N; Asiar, R.M., R. (2019). Entrepreneurial Behavior and Intentions among Bumiputera's Students, Global J. Bus. Soc. Sci. Review 7(4): 239 - 247. https://doi.org/10.35609/gjbssr.2019.7.4(4)

JEL Classification: G100, I20.

\section{Introduction}

By 2020, the world's economic situation is expected to be more competitive due to the effects of globalization, such as free trade, advancement in technology and information, and diverse new opportunities that contribute to the destabilization of the business sector (Mwatsika and Sankhulani, 2016).

\footnotetext{
* Paper Info: Revised: September 11, 2019

Accepted: December 31, 2019

* Corresponding author: Norasmah Othman

E-mail: lin@ukm.edu.my

Affiliation: Faculty of Education Universiti Kebangsaan Malaysia, 43600 Bangi, Selangor, Malaysia
} 
Numerous studies have found that the entrepreneurial sector is an important alternative driver of a nation's economy that directly increases job opportunities (Mohamad, Abdullah, and Bakar, 2015; Nafukho and Muyia, 2010). Studies from several countries, such as Malawi, Indonesia, India, South Africa, Greece, and Malaysia proved that entrepreneurship not only stabilized the country's economy, but also shaped its innovation, which increased business competitiveness, job opportunities, and individual incomes (Ghina, 2014; Mwatsika and Sankhulani, 2016). Countries that want to develop proactive human capital, an innovative economy, and high income need to invest in entrepreneurship education (Othman, Khasbullah, and Wahid, 2015). Currently, most countries - including Malaysia -have planned a variety of entrepreneurship programs at the school and university levels to enhance young people's entrepreneurship knowledge and skills (O'Connor, 2013; Radin, Othman, and Pihie, 2017). Malaysia introduced entrepreneurship education in the early 1900s; however, it was only in 2007 that the entrepreneurship module was made compulsory or offered as a field of study at universities. At present, every educational institution plays a role in shaping entrepreneurs through a variety of programs and educational activities that target students in schools and universities (Hamidon and Ali, 2016).

\section{Literature Review}

Human behavior includes physical manifestations and thus has observable, illustrative, measurable, and recordable dimensions based on the period and intensity of the behaviors exhibited. In fact, these can be influenced systematically by the environment each individual is exposed to (Nagarathanam and Buang 2015). Nagarathanam and Buang (2015) also stated that such behavior is shown explicitly or implicitly and changes due to the individuals' environmental circumstances.

Previous studies indicate that early entrepreneurial exposure has effects on an individual's behavior and intention in choosing an entrepreneurial career (Peterman and Kennedy 2003). According to Mohamad, Abdullah, and Abu Bakar (2015), a high level of entrepreneurial behavior is important for enabling students to think analytically, openly, flexibly, and strategically. Hassan dan Buang (2017) states that developing graduates' entrepreneurial behavior is important as this can indirectly generate entrepreneurial intentions. Entrepreneurial behavior is essential in the entrepreneurial process and is key to determining whether an individual venture into entrepreneurship (Bryant 2006). The entrepreneurial process starts with the intention and is followed by the identification and evaluation of opportunities within the period of deciding to venture into entrepreneurship (Bryant 2006). Hence, the concept of entrepreneurial choice has been the focus of many studies in the entrepreneurship field, leading to it becoming a main aspect in defining entrepreneurship (Bryant 2006).

Intention is an element in an individual that makes them act on a specific behavior (Fayolle \& Liñán, 2014). According to Krueger, Reilly, and Carsrud (200), having consistent and strong intentions can help predict an individual's behavior. Based on the theory of reasoned action by Fishbein and Ajzen (1975), intention is a determinant for success in behavior as it complements the individual's personality and attitude. Theories are widely used to predict entrepreneurial intentions. According to Shapero and Sokol (1982) and Krueger and Carsrud (1993), the tendency to act is a key factor in influencing entrepreneurial intention.

The combination of both entrepreneurial behavior and intention could convince individuals, especially students, to involve themselves with entrepreneurship. As such, various activities and programs are being implemented for this purpose with the funds and support from the Malaysian government; however, reports suggest otherwise. According to the Global Entrepreneurship Monitor (GEM 2011) statistics report, Malaysia had the lowest percentage of people choosing entrepreneurship as their career (51.5\%) compared to other Asian countries such as Thailand (77\%) and China (73.1\%). Since 2017, as hiring rates decreased in Malaysia, unemployment increased. According to the World Bank (2017), the Malaysian economy is expected to shrink by $4.8 \%$ in 2019 . This is the reason that most government-linked companies and small 
businesses are closing and reducing job offers. Berita Semasa's (2018) report states that three out of five Malaysian university graduates are unemployed.

The number of public and private higher education institutions in Malaysia has increased, but this does not reflect on the quality of graduates produced (Othman et al., 2015), which remains debatable. Employers reject graduates for poor English-speaking skills and a lack of soft skills and competitiveness (Mohamed, 2014). At present, to reduce operating costs, employers hire experienced individuals with diverse skills (Eriniawati, 2014).

Therefore, this study examines whether entrepreneurial culture has been promoted among students, especially in Bumiputera's private colleges in cities such as Kuala Lumpur. Given the high cost of living in these cities, what is the level of students' entrepreneurial behavior and intentions? Are these students interested in an entrepreneurial career? To address these questions, we identified the level of students' behaviors and intentions concerning an entrepreneurial career and examined the relationship between the two based on the student's background. As the number of young entrepreneurs continues to increase, this study will enable private college administrators and the ministry of education to improve the existing business curriculum and teaching methods.

\section{Methodology}

This quantitative study conducted a survey using a questionnaire divided into three sections: part A contains nine items measuring entrepreneurial behavior, part B contains ten items identifying entrepreneurial intentions, and part $\mathrm{C}$ contains seven items assessing the respondent's background. The items for measuring entrepreneurial behavior were adapted from several studies, including Hassan and Buang (2017), while the tools for identifying entrepreneurial intention were adapted from Othman and Othman (2015). These were measured using a four-point Likert scale ranging from 1 (strongly disagree) to 4 (strongly agree). In terms of reliability, the Cronbach's alpha values ranged from 0.867 to 0.902 , which exceeds 0.6 , and the validity of each construct based on the correlation of the corrected item ranged from 0.397 to 0.783 . This indicates that the instrument is good as its validity is greater than 0.3 (Konting, 2005). Table 1 was used as a guide to assess the level of entrepreneurial behavior and entrepreneurial intention.

Table 1: Mean Score and Interpretation

\begin{tabular}{|c|c|}
\hline Mean Score & Interpretation \\
\hline $1.00-2.00$ & Low \\
\hline $2.01-3.00$ & Moderate \\
\hline $3.01-4.00$ & High \\
\hline
\end{tabular}

Source: Konting, 2015

Participants in this study included students involved in all diploma levels and various majors at a Bumiputera private college in Kuala Lumpur. Sample size determination was based on Krejcie and Morgan's (1970) table, whereby a population of 2,192 warranted a sample of 327 . However, in this study the researchers used 387 samples, which exceeded the requirements set out in Cohen et al. (2007) to achieve $70 \%$ to $80 \%$ survey returns. The increased number of samples aimed to avoid a situation in which a large number of questionnaires remained unanswered. Subsequently, sample selection was made in a randomized cluster where 13 classes were selected from 30 combined study programs and semesters. Only 30 samples were selected to represent each of these classes, leading to a total of 390 samples. Finally, 387 completed 
questionnaires were analyzed using the Statistical Package for Social Science version 22.0, which used descriptive and inference tests. Table 2 presents the overall demographic profile of these 387 respondents.

Table 2. Respondent Demographic Profile

\begin{tabular}{|c|c|c|c|}
\hline $\begin{array}{c}\text { Demographic } \\
\text { Profile }\end{array}$ & Category & Frequency & $\begin{array}{c}\text { Percentage } \\
(\%)\end{array}$ \\
\hline \multirow[t]{2}{*}{ Gender } & Male & 136 & 35.1 \\
\hline & Female & 251 & 64.9 \\
\hline \multirow[t]{2}{*}{ Educational Stream } & Business & 179 & 46.2 \\
\hline & Non-Business & 208 & 53.8 \\
\hline \multirow{2}{*}{$\begin{array}{c}\text { Family with } \\
\text { Business }\end{array}$} & Yes & 116 & 30 \\
\hline & No & 271 & 70 \\
\hline \multirow{2}{*}{$\begin{array}{c}\text { Business } \\
\text { Experience }\end{array}$} & Yes & 207 & 53.5 \\
\hline & No & 180 & 46.5 \\
\hline \multicolumn{4}{|c|}{ Experience Type } \\
\hline \multirow[t]{3}{*}{ Business* } & Part-time & 167 & 57 \\
\hline & Entrepreneurial Program & 118 & 77 \\
\hline & Helping family/acquaintance & 132 & 63 \\
\hline \multicolumn{4}{|c|}{ Work Experience } \\
\hline \multirow[t]{3}{*}{ Business: } & 1 to 2 years & 225 & 58.4 \\
\hline & 3 to 4 years & 100 & 25.6 \\
\hline & 5 to 6 years & 62 & 16 \\
\hline
\end{tabular}

* Respondents could choose more than one source of experience, $\mathrm{n}=387$

\section{Findings and Discussion}

\subsection{Objective 1: Measuring the Level of Entrepreneurial Behavior among Bumiputera Private College Students}

Table 3 shows that Bumiputera private college students have a moderate level of entrepreneurial behavior $(M=2.70, s d=0.58)$, as can be seen in Table 3. These findings support those of Hassan and Buang (2017) study, which showed that the entrepreneurial behavior among public university students was at a moderate level. Othman and Othman (2015) found that the entrepreneurial career choice of 469 students in several public universities was also at a moderately high level. According to Table 3, item 4 had the lowest "Agree" $(\mathrm{SA}+\mathrm{A})$ percentages, with only $43.7 \%$ of students attending externally sponsored entrepreneurship courses or workshops. Similarly, for item 6 in Table 3, only $48.5 \%$ (SA + A) of students were involved in sales activities organized by any agency. These findings suggest that students need to be influenced by a culture that seeks knowledge and skills; they specifically need involvement with external agencies to enhance their self-confidence and communication skills. According to Mohamad et al. (2015), interpersonal communication skills enable students to compete in the globalized world and help them build good relationships for future business networks. Moreover, Mohamad et al. (2015) suggested that students also need high levels of entrepreneurial behavior to develop their analytical, flexible, strategic, and open thinking skills more effectively. Therefore, measures that improve the entrepreneurial behavior of private college students should be implemented. 
Table 3: Level of Entrepreneurial Behavior Analysis

\begin{tabular}{|c|c|c|c|c|}
\hline Item & \multicolumn{3}{c|}{ Percentage (\%) } \\
\hline & SD & D & A & SA \\
\hline Attend college organized entrepreneurship courses/workshops. & 4.4 & 26.6 & 46.3 & 22.7 \\
\hline Sell items among friends while in college & 6.2 & 24.8 & 43.7 & 25.3 \\
\hline Join the Entrepreneurship Club during college. & 13.4 & 31.0 & 32.0 & 23.5 \\
\hline $\begin{array}{c}\text { Participate in entrepreneurship workshops/courses organized by } \\
\text { any external institution. }\end{array}$ & 9.3 & 47.0 & 33.1 & 10.6 \\
\hline Seek desired business advice from experienced entrepreneurs. & 6.7 & 38 & 40.8 & 14.5 \\
\hline Engage in sales activities organized by any agency. & 10.3 & 41.1 & 35.1 & 13.4 \\
\hline Talk to others about a business idea. & 7.2 & 23.5 & 51.2 & 18.1 \\
\hline $\begin{array}{c}\text { Seek information on how to start a business from a variety of } \\
\text { sources. }\end{array}$ & 4.4 & 22.7 & 49.4 & 23.5 \\
\hline $\begin{array}{c}\text { Get advice from government/private agencies on } \\
\text { entrepreneurship opportunities. }\end{array}$ & 6.2 & 25.3 & 47.0 & 21.4 \\
\hline $\begin{array}{c}\text { Mean Score } \\
\text { Standard Deviation }\end{array}$ & & \\
\hline $\begin{array}{l}\text { Level } \\
\text { * SD = Strongly Disagree, D = Disagree, A = Agree, SA = Strongly Agree }\end{array}$ \\
\hline
\end{tabular}

\subsection{Objective 2: Measuring the Level of Entrepreneurial Intention among Bumiputera Private College Students}

Table 4 shows that the students' entrepreneurial intentions are moderate, with a mean score of 2.85 ( $\mathrm{sd}=$ 0.55). According to Table 4, the lowest approval scores are for items 7 and 8: only $55.3 \%$ of students indicated that they intended to start a business within the next 5 years and the next 10 years, respectively. Similarly, in item 3, only $61.2 \%$ of students stated that they were willing to do anything to become entrepreneurs. Although the entrepreneurial intentions are moderate, this finding reflects growth potential, with a majority $(67.5 \%)$ of the surveyed students choosing entrepreneurship as their preferred career (item 1), although students remain less confident about undertaking the risk of starting a business within a short period after graduation. This finding coincides with that of Othman and Othman (2015), who showed that entrepreneurial intentions in public universities are also at a moderate level, and that students lack confidence in their ability to become entrepreneurs. Improvements should be made to the hands-on curriculum, including direct or online sales activities related to students' respective fields (e.g., Hotel Management and Catering should be taught in the food and catering business). Lecturers also need entrepreneurial training to equip them with the latest and most exciting teaching methods to engage more students in entrepreneurship (Othman and Amirrudin 2016). Students should be encouraged to have high levels of entrepreneurial behavior and intentions towards entrepreneurship as a career (Al-Haj and Yusof, 2013).

Table 4: Level of Entrepreneurial Intention Analysis

\begin{tabular}{|c|c|c|c|c|}
\hline Item & \multicolumn{3}{|c|}{ Percentage (\%) } \\
\hline Choose entrepreneurship as a career & SD & D & A & SA \\
\hline $\begin{array}{c}\text { Company. } \\
\text { choose to be an entrepreneur rather than an employee at a }\end{array}$ & 5.9 & 26.6 & 49.4 & 18.1 \\
\hline Be willing to do anything to become an entrepreneur. & 5.9 & 32.3 & 44.4 & 18.1 \\
\hline Try to do whatever it takes to run my own business. & 2.8 & 20.7 & 54.4 & 16.8 \\
\hline Have the desire to start a business one day. & 1.8 & 18.9 & 54.5 & 24.8 \\
\hline
\end{tabular}




\begin{tabular}{|c|c|c|c|c|}
\hline Think seriously about starting a business after graduating. & 3.4 & 33.1 & 46.5 & 17.1 \\
\hline Intend to start a business within the next 5 years. & 4.9 & 39.8 & 42.9 & 12.4 \\
\hline Intend to start a business within the next 10 years. & 4.9 & 39.8 & 45.2 & 10.1 \\
\hline Make sure to have a business in the future. & 2.1 & 19.1 & 51.9 & 26.9 \\
\hline Be an employer or leader in your own organization. & 1.6 & 14.2 & 49.4 & 34.9 \\
\hline Mean Score & \multicolumn{4}{|c|}{2.85} \\
\hline Standard Deviation & \multicolumn{4}{|c|}{ Moderate } \\
\hline Level & \multicolumn{4}{|c|}{} \\
\hline
\end{tabular}

* SD = Strongly Disagree, D = Disagree, A= Agree, SA = Strongly Agree

\subsection{Objective 3: Identifying the Relationship between the Entrepreneurial Behavior and Entrepreneurial Intention of Bumiputera Private College Students}

Table 5 shows that there is a significant positive relationship between students' entrepreneurial attitudes and their entrepreneurial intentions $(\rho=0.595, \mathrm{p}<0.05)$. According to Sekaran (2006), the strength of the relationship is moderate with correlation values ranging from 0.40 to 0.60 . The findings of this study illustrate that the entrepreneurial behavior of students is less helpful in enhancing entrepreneurial intentions. Students lack exposure to the entrepreneurial world and receive an ineffective entrepreneurship education from their family or during college. A student's entrepreneurial intentions can be stifled without exposure and experience, or with only a moderate level of entrepreneurial behavior (Mwatsika, C., and Sankhulani, E. 2016; Othman and Othman 2015).

Table 5: The Correlation between the Entrepreneurial Behavior and Entrepreneurial Intention of Bumiputera Private College Students

\begin{tabular}{|l|c|c|}
\hline Variable & Correlation Value $(\rho)$ & Significant Value $(\mathrm{p})$ \\
\hline Behavior & 0.595 & $0.00^{*}$ \\
\hline \multicolumn{2}{|c}{ *Correlations are significant at 0.01 level. } \\
\hline
\end{tabular}

\subsection{Objective 4: Identifying Different Levels of Entrepreneurial Intention in Bumiputera Private College Students}

The results (t-value $=-0.964, p>0.05$ ) indicate there is no significant difference between the level of entrepreneurial intention of business students and that of non-business students (see Table 6). This supports Hassan and Buang's (2017) research on UTM graduate alumni, which showed that the educational majors chosen is not a factor that drives alumni to become entrepreneurs. However, entrepreneurial opportunities can generate lucrative income and provide employment that solidifies the intentions of students, who are not in the business stream, to pursue entrepreneurial careers.

\subsection{Objective 5: Identifying Different Levels of Entrepreneurship in Bumiputera Private College Students Based on Family Background}

Table 6 shows that there is a significant difference between the level of entrepreneurial intention in students from families that have a business background and those that do not $(\mathrm{t}$-value $=3.98, \mathrm{p}<0.05)$. This finding indicates that family background impacts entrepreneurial intentions. Students who are exposed to the entrepreneurial world at a young age are more likely to start a business: be it joining an established family business or getting involved in a new business. According to Mutalib (2013), students from entrepreneurial families have higher entrepreneurial tendencies. This suggests that students with a business family background are more motivated to follow the same career path as their families. 
Table 6. Analyzing the difference between Intentions and Educational Stream, Family with Business, and Business experience

\begin{tabular}{|c|c|c|c|c|c|c|}
\hline Variables & $\mathrm{n}$ & Mean & S.D. & \multicolumn{1}{c|}{$\mathrm{t}$} & $\mathrm{P}$ \\
\hline \multicolumn{7}{|c|}{ Educational Stream } \\
\hline Business Program & 162 & 2.81 & 0.64 & -0.964 & 0.356 \\
\hline Non-Business Program & 225 & 2.87 & 0.49 & & \\
\hline \multicolumn{7}{|c|}{ Family with Business } \\
\hline Yes & 116 & 3.01 & 0.49 & 3.98 & 0.00 \\
\hline No & 271 & 2.77 & 0.57 & & \\
\hline Yesiness Experience & 207 & 2.96 & 0.52 & 4.29 & 0.00 \\
\hline Yo & 180 & 2.72 & 0.57 & & \\
\hline
\end{tabular}

\subsection{Objective 6: Identify Different Levels of Entrepreneurial Intention in Bumiputera Private Colleges based on Students' Business Experience}

There was a significant difference between the entrepreneurial intentions of students with business experience and those without business experience (Table 6: $t$-value $=4.29, p<0.05$ ). Students with business experience have higher entrepreneurial intentions than students who have no prior business experience. According to Table 2, most students (58.4\%) had only one to two years of business experience, while $16 \%$ of students had 5-6 years of experience. Whah (2003) studied Malay and Chinese entrepreneurs, and found that factors such as entrepreneurial experience, self-motivation, and family influence entrepreneurs' success. Table 2 shows how students gained entrepreneurial experience (students could choose more than one option): $77 \%$ of students gained experience by participating in entrepreneurship programs, $63 \%$ helped with their family's business, and 57\% worked part-time. According to Hamidon et al. (2016) continuous experience enhances students' entrepreneurial intentions. Students can be encouraged to start a business after graduating through practical training with successful entrepreneurs as mentors, and through early capital assistance or micro-lending collaboration between colleges and corporate companies.

\section{Conclusion}

Malaysia needs to expand its entrepreneurship education to generate human capital, which will drive the country's economy toward becoming a developed nation, solve the unemployment problem, and meet the market's demand for quality graduates. Thus, many countries prioritize entrepreneurship education, hoping that having more entrepreneurs will alleviate the country's problems. In addition, various programs have been introduced so that entrepreneurial behavior and intention among students can be increased. However, after more than three decades, the percentage of student involvement in entrepreneurship is still low. Therefore, the study was conducted to assess the level of entrepreneurial behavior and intention, and analyze the correlation between the two.

Our findings show that students' entrepreneurial behavior and intentions are still at a moderate level, and there is a significant positive, although moderate, relationship between the two. Furthermore, the results showed no significant differences between the entrepreneurial intentions of business and non-business students. However, more than half of the students involved in this study became entrepreneurs instead of corporate employees. This study can help the ministries, college administrators, and lecturers improve their curriculum, teaching methods, and practical training. 


\section{Acknowledgements}

The authors would like to thank the reviewers. We would also like to thank the Centre of Leadership and Educational Policy, Faculty of Education, Universiti Kebangsaan Malaysia for funding this article (GG-2018012) and (GG-2019-06).

\section{References}

Alhaj, B. K., \& Yusof, M. Z. (2012). Entrepreneurial Attitude and Entrepreneurial Desire: An Evaluation of Instruments in the Study of Entrepreneurship Tendencies. Malaysian Journal on Student Advancement, (15). http://spaj.ukm.my/personalia/index.php/personalia/article/view/38

Current news. (2018). University Graduates 56 percent of Malaysian unemployed out of 385k (University Graduate 56 percent unemployed out 385k). https://www.beritasemasa.com.my/graduates-university-professional-Malaysia. Achieved on 19 August.

Bryant, P. T. (2006). Improving entrepreneurial education through self-regulatory skills. In Venture Well. Proceedings of Open, the Annual Conference (p. 279). National Collegiate Inventors \& Innovators Alliance. https://pdfs.semanticscholar.org/ed70/1e48f3ad0942ecfd91b00464014005a86895.pdf

Cohen L., Manion L., Morrison K. (2007). Research Methods in Education. 6th ed. London and New York: Routledge Taylor \& Francis Group.

Miaat, E. A. (2014). Factors driving vocational college students' interest in entrepreneurship (Doctoral dissertation, University of Tun Hussein Onn Malaysia). http://eprints.uthm.edu.my/id/eprint/7082/

Fayolle, A., \& Liñán, F. (2014). The future of research on entrepreneurial intentions. Journal of Business Research, 67(5), 663-666. https://doi.org/10.1016/j.jbusres.2013.11.024

Fishbein, M., \& Ajzen, I. (1977). Belief, attitude, intention, and behavior: An introduction to theory and research. https://philarchive.org/archive/FISBAI

Ghina, A. (2014). Effectiveness of entrepreneurship education in higher education institutions. Procedia-Social and Behavioral Sciences, 115, 332-345. https://core.ac.uk/download/pdf/82048735.pdf

Global Entrepreneurship Monitor (GEM) (2011). Global Entrepreneurship Monitor. Global Report.

Hamidon I. N., Ali K. A. M. (2016). The role of the University as a guide toward student's entrepreneurship inclination. Journal of Global Business and Social Entrepreneurship (GBSE), 1 (1), 48-54.

Hassan A., Remove N. A. (2017). Comparison of entrepreneurial attitude, thinking and entrepreneurial behavior with business plan level among science students. Journal of Global Business and Social Entrepreneurship (GBSE), 1 (1), 8699.

International Labour Organization. (2017). Global Employment Trends for Youth 2017. Geneva-ILO. http://www/ilo.org.

Konting, M. M. (2005). Research education methods. Kuala Lumpur: Library Language Council.

Krejcie, R. V., \& Morgan, D. W. (1970). Determining sample size for research activities. Educational and psychological measurement, 30(3), 607-610. https://doi.org/10.1177/001316447003000308

Krueger Jr, N. F., Reilly, M. D., \& Carsrud, A. L. (2000). Competing models of entrepreneurial intentions. Journal of business venturing, 15(5-6), 411-432. https://doi.org/10.1016/S0883-9026(98)00033-0

Krueger, N. F., \& Carsrud, A. L. (1993). Entrepreneurial intentions: Applying the theory of planned behaviour. Entrepreneurship \& Regional Development, 5(4), 315-330. https://doi.org/10.1080/08985629300000020

Mohamad, A., Abdullah, S., Bakar, A., \& Julienti, L. (2015). Transformation of entrepreneurial thinking to dimensions of entrepreneurship opportunities among the disabled. Journal of Global business and Social Entrepreneurship.

Mohamed, M. F. B. (2014). Implementation of soft skills in the context of leadership building in students through curricular activities at university. Faculty of Technical and Vocational Education. Tun Hussein Onn University.

Mutalib, S. (2013). A review of entrepreneurial tendencies among students at Public Institutions of Higher Learning. Journal of Social Techno, 5 (1). https://publisher.uthm.edu.my/ojs/index.php/JTS/article/view/1411

Mwatsika, C., \& Sankhulani, E. (2016). Effect of entrepreneurship education on students' orientation towards entrepreneurship at the Malawi Polytechnic. International Journal of Business and Economic Research, 5(6), 235-245. doi: $10.11648 /$ j.ijber.20160506.17 
Nagarathanam, R., \& Throw, N. A. (2016). The Relationship between Attitude, Intention, and Entrepreneurship Career Choice among Malaysian Indian Undergraduates. Academic, 86 (2).

Nafukho, F., Nafukho, F. M., \& Muyia, M. A. H. (2010). Entrepreneurship and socioeconomic development in Africa: a reality or myth? Journal of European Industrial Training. https://doi.org/10.1108/03090591011023961

O'Connor, A. (2013). A conceptual framework for entrepreneurship education policy: Meeting government and economic purposes. Journal of Business Venturing, 28(4), 546-563. https://doi.org/10.1016/j.jbusvent.2012.07.003

Othman N., Amirrudin M. H. (2016). Teaching the Basics of Entrepreneurship Based on Mastery Strategy. Kuala Lumpur: Library Language Council.

Othman, N., \& Othman, N. H. (2015). Relationship between entrepreneurial intentions and entrepreneurial career choice behavior among university students. Journal of Business and Economics, 6(1), 179-186. https://www.researchgate.net/profile/Norasmah_Othman/publication/281854331_Relationship_between_Entrepreneuria 1_Intentions_and_Entrepreneurial_Career_Choice_Behavior_among_University_Students/links/565450a608ae4988a7b 01c3c/Relationship-between-Entrepreneurial-Intentions-and-Entrepreneurial-Career-Choice-Behavior-amongUniversity-Students.pdf

Othman, N., Khasbullah, K. K., \& Ab Wahid, H. (2015). Competitiveness Level of Higher Education Institution Students in Peninsular Malaysia. Malaysian Journal of Education (MJE), $40 \quad$ (2), 139-149. http://ejournals.ukm.my/jpend/article/view/13234

Peterman, N. E., \& Kennedy, J. (2003). Enterprise education: Influencing students' perceptions of entrepreneurship. Entrepreneurship theory and practice, 28(2), 129-144. DOI: 10.1046/i.1540-6520.2003.00035x

Radin, R. S. A., Rahman, A., Othman, N., \& Pihie, Z. A. L. (2017). Social entrepreneurial intention among students of different status and university category. International Journal of Economic Research, 14(15), 377-394. https://ukm.pure.elsevier.com/en/publications/social-entrepreneurial-intention-among-students-of-different-stat Sekaran, U. (2006). Research Method for Business: A Skill Approach; John Willey and Sons. Inc. New York. Shapero, A., \& Sokol, L. (1982). The social dimensions of entrepreneurship. Encyclopedia of entrepreneurship, 72-90. https://papers.ssrn.com/sol3/papers.cfm?abstract_id=1497759

Chin, Y. W. (2003). Chinese culture and entrepreneurship in Malaysia. Publisher of National University of Malaysia. World Bank. (2017). Malaysia Economic Monitor Reports. http://www.nst.com.my. 